\title{
Representações dos profissionais do desporto acerca do conceito de competência profissional
}

CDD. 20.ed. 371.12

\author{
Paula Maria Fazendeiro BATISTA* \\ Zélia Maria Roque Pinto MATOS* \\ Isabel Maria Ribeiro MESQUITA* \\ Amândio Braga dos Santos GRAÇA* \\ ${ }^{\star}$ Centro de Investiga- \\ ção, Formação e Inter- \\ venção em Desporto, \\ Universidade do Porto \\ - Portugal.
}

\begin{abstract}
Resumo
0 campo de intervenção do profissional do desporto tem vindo a alargar-se e, concomitantemente, a complexificar-se. As ocupações tradicionais adstritas ao ensino e ao treino sofreram metamorfoses, aumentando as dificuldades de conceitualização de competência profissional. Neste estudo, procura-se identificar o conceito que os profissionais do desporto denotam de profissional competente, na persecução da identificação de um mapa conceitual transversal às quatro áreas ocupacionais consideradas: Educação Física, Treino, Atividade Física Adaptada e "Fitness". Foram entrevistados 120 profissionais (30 de cada área ocupacional) sobre o conceito de competência e de profissional competente. Na análise dos dados, utilizaram-se procedimentos de análise de conteúdo. Os resultados são ilustrativos da frágil conceitualização que ainda caracteriza o campo do profissional do desporto. Identificam-se, contudo, traços comuns que apontam para a busca de uma unidade identitária centrada na competência de conhecimento e ética coadjuvada pela competência pessoal e social em estreita articulação com a competência funcional, sendo que as metacompetências e a motivação são fatores valorizados, os quais assumem a função de sustentação da competência profissional.
\end{abstract}

Unitermos: Conceção de competência; Profissões do desporto; Competências profissionais.

\section{Introdução}

No atual contexto do mercado de trabalho, a convergência de fatores tão díspares como a internacionalização, a interdependência transnacional, as mudanças tecnológicas e o acesso à informação fazem emergir um novo paradigma profissional e, obviamente, um "novo tipo de profissional", onde a flexibilidade, a criatividade e a diferenciação são fatores distintivos (LOPEs, 2002).

À semelhança de outros setores profissionais, o campo profissional do desporto também foi influenciado por estas transformaçōes. Acresce que a prática desportiva se estendeu a outros contextos, acarretando um crescimento exponencial do número de praticantes e o desenvolvimento de um conjunto de ocupações distintas das tradicionalmente adstritas ao ensino e ao treino. Algumas destas ocupações mantêm o seu enfoque predominantemente pedagógico, assumindo todavia especificidade em função dos contextos de prática (ginásios, clubes, instituiçōes de solidariedade, etc.). Por sua vez, outras são especificações de ocupações já existentes, nomeadamente as que aparecem no âmbito das atribuiçōes da equipe de apoio ao treinador de alto rendimento, enquanto outras não têm uma dimensão pedagógica, como sejam, as ocupações ligadas à gestão.

Esta nova realidade coloca problemas acrescidos na já difícil tarefa de determinar o que é um profissional competente. BURGOYONE (1993) refere que em cada campo profissional são enfatizados diferentes aspetos. Mormente, a título de exemplo, denota-se que, no campo da gestão, a função tende a ser valorizada; no da educação, a formação e o conhecimento; ou ainda, na gestão de recursos humanos, a centralidade dos processos é conferida à pessoa.

O entendimento de competência profissional, tal como o conceito de competência que lhe é adstrito, tem aumentado na utilização e diminuído na precisão. 
LySAght e Altschld (2000), preocupados não só com a conceção de competência profissional mas também com a forma de a regular, apresentaram um conjunto de definições de competência profissional pretensamente ilustrativas das principais conceções de competência. Neste âmbito, autores como GonZI (1994) e Hager e Gonzi (1996) apontam três grandes aproximações na análise da competência nas profissões: 1) aproximação comportamental, centrada nos papéis e tarefas, em que a avaliação do desempenho é por observação direta; 2) aproximação genérica, centrada no perfil do trabalhador, na qual os atributos individuais (conhecimentos, habilidades e atitudes) permitem diferenciar o trabalhador eficiente do trabalhador comum; 3) aproximação integrada, relacional ou holistica, resultante da combinação complexa de atributos e funções, onde, dependendo da situação, o profissional aplica os atributos necessários à resolução eficaz.

Reforçando a ideia de conceitualizações diferenciadas de competência profissional, refira-se, a título ilustrativo, a evolução do entendimento de competência no âmbito da gestão apresentada por Hong e STÂHLE (2005). Os autores referem que a competência profissional começou por ser entendida como a aquisição de conjunto de recursos, passou pela fase em que o entendimento se situava na "integração de capacidades", até à fase mais recente, em que a competência é vista como o resultado de uma construção prática, sendo que o ponto central está na produção de recursos ou novas competências. Deste modo, passou-se gradualmente de uma perspetiva funcionalista, associada a aproximaçôes racionalistas, para uma perspetiva estruturalista, interligada com aproximações mais interpretativas.

Ao nível do profissional do desporto, a pluralidade de contextos de prática aporta dificuldades acrescidas na já complexa conceitualização da competência profissional. Considerando que cada contexto se caracteriza por diferentes propósitos (formação, rendimento, recreação, bem-estar, ...), com uma estrutura própria (escola, clubes, ginásios, instituições de solidariedade, ...), e que a competência é situacional e específica (Batista, Graça \& Matos, 2007; KirshHner, Vilsteren, Hummel \& Wigman, 1997), surge como premente a necessidade de reequacionar as questōes da competência profissional. Desde logo, importa clarificar se é lícito considerar um entendimento unânime e transversal de competência do profissional do desporto que atua em diferentes contextos de prática desportiva, ou, pelo contrário, equacionar a competência ocupação a ocupação, atendendo às especificidades próprias de cada uma.
A aceitação da ideia de que os contextos, na perspetiva pedagógica, de intervenção do profissional do desporto se integram num âmbito mais vasto, que é o desporto enquanto atividade polissémica e polimorfa (BENTO, 1999), sugere a existência de uma competência chave transversal, capaz de responder a múltiplas funçōes. WeInERT (2001, p.52) presenteia-nos com uma conceitualização de competência chave apresentada sob a seguinte fórmula: competência chave $=$ competência + "tranversalidade"/multifuncionalidade + importância. Por sua vez, RYCHEN e SALGANIK (2003, p.54) referem que "... a noção de competências chave é usada como sinônimo de competências críticas e importantes para todos os indivíduos e para as diferentes esferas da vida". As noçôes de "núcleo da competência" e "transversalidade da competência" marcam o discurso destes autores.

Por sua vez, WeInerT (2001, p.53) sugere uma classificação para as competências chave: competências sociais; competência pessoal, competência metodológica, competência factual/técnica. Reforçando a ideia de competências chave, embora sob a designação de competências nucleares, CHEETHAM e CHIVERS (1996, 1998) incorporam no seu modelo de competência profissional quatro grupos de competências: conhecimento/competência cognitiva; competência pessoall social; valores/competência ética; competência funcional. $\mathrm{O}$ entendimento da interrelação e interdependência das competências chave/nucleares caracteriza o entendimento dos autores, embora com diferentes abrangências. Enquanto WeINERT (2001) acentua as questôes metodológicas e incorpora as questões éticas nas competências sociais e pessoais, CHEETHAM e CHIVERS (1998) assumem a competência ética separadamente e incorporam as questôes metodológicas na componente funcional, mais lata.

Assim, o investimento na identificação da representação de competência dos profissionais do desporto que intervêm em diferentes contextos de prática desportiva parece constituir-se um aspeto relevante no processo de clarificação dos elementos que marcam o conceito de competência profissional, tendo em vista a identificação da(s) competência(s) chave da noção de competência do profissional do desporto.

Baseado neste quadro conceitual de referência, o objeto deste estudo foi identificar a representação que os profissionais do desporto denotam de profissional competente. Procurou-se, ainda, verificar se existe uma conceitualização de competência profissional suficientemente consistente, capaz de conferir uma identidade própria ao campo do profissional do desporto, bem como identificar os vetores estruturantes da mesma. 


\section{Material e métodos}

\section{Participantes}

Participaram no estudo 120 sujeitos de ambos os sexos - 64 do sexo masculino e 56 do sexo feminino - com 30 elementos de cada área profissional. As idades estavam compreendidas entre os 23 e os 58 anos, sendo que a média se situou nos 36,35 anos e o desvio-padrão em 8,26 anos. A experiência profissional variou entre um e 30 anos, com uma média de 12,20 e um desvio-padrão de 7,08. Tomando como referência genérica a delimitação estabelecida no projeto AEHESIS (DUfFY, 2008), o presente estudo é circunscrito aos contextos de ensino e treino, ficando excluídas as áreas ocupacionais ditas não-pedagógicas. Deste modo, foram consideradas quatro áreas de ocupação profissional no âmbito do desporto: Educação Física, Treino Desportivo, Atividade Física Adaptada e "Fitness", atendendo ao fato de serem as culturalmente fundados na sociedade desportiva portuguesa. Os professores de $\mathrm{EF}$ e os treinadores apresentaram uma média de anos de experiência profissional mais elevada que os profissionais de populaçôes especiais e os profissionais de "fitness" (respetivamente 17,77 e $14,20$ vs. 9,07 e 9,03$)$.

Ao nível do regime de exercício profissional, 33 elementos exerciam a atividade em exclusividade e $87 \mathrm{em}$ mais que uma atividade profissional, sendo que na área do "fitness" se verificou um equilíbrio entre o número de profissionais em exclusividade e os que acumulavam outras ocupações. Nas restantes ocupaçōes, a grande maioria exercia a atividade em acumulação.

\section{Instrumento e coleta de dados}

Para a coleta dos dados, utilizou-se a entrevista, face ao fato de esta se assumir como a técnica mais adequada ao propósito do estudo. GRATTON e JONES (2004, p.140) referem que a "entrevista é adequada à coleta de dados relacionados com conceitos irredutíveis à quantificação e tende a dar preferência às questôes da ordem do porquê e do como sobre as do quanto e do quando".

De entre os tipos de entrevistas, foi selecionada a semiestruturada em detrimento da não estruturada, em virtude da maior segurança que aquela proporciona, sem com isso deixar de permitir uma condução flexível, ao admitir a alteração da ordem das questōes e ao procurar mais informação através da introdução de questôes subsidiárias (GRATTON \& JONES, 2004).

O guião da entrevista semiestruturada foi constituído por seis questóes de resposta aberta. A elaboração do guião teve como base o quadro teórico dos modelos de competência profissional mais discutidos na literatura (CHEETHAM \& Chivers, 1998; HAger \& GONZI, 1996; KirsShHner et al., 1997; Velve, 2000; Westera, 2001). As questōes procuraram detetar a representação de competência através de questões de opinião, de valor e de experiência de vida. $\mathrm{O}$ conteúdo da entrevista foi alvo de análise por três "experts" (Doutorados e especialistas da área de Pedagogia do Desporto), no sentido de identificar se as questôes consideradas respondiam à totalidade dos problemas em estudo. Foi ainda efetuado um estudo piloto com três participantes, no sentido de se aferir acerca da compreensão, inteligibilidade e clareza das questôes.

As entrevistas foram realizadas durante o ano de 2008 e tiveram uma duração entre os 25 minutos e uma hora e 30 minutos, com uma duração média de 55 minutos. Estas aconteceram em ambientes calmos e reservados, sem ninguém a assistir. As questōes foram colocadas da mesma forma e o leque de esclarecimentos e redirecionamento de dúvidas foi controlado com parcimônia. Os respondentes deram o seu consentimento voluntário e o anonimato foi garantido.

As entrevistas foram gravadas em áudio e posteriormente transcritas verbatim para computador. A fiabilidade da transcrição foi garantida pela audição e confirmação de extratos de texto ou palavras, com a ajuda do programa digital Voice 2, que permite recuar e repetir extratos de texto específicos. Os textos transcritos foram formatados na modalidade só texto (txt) e introduzidos no programa de análise de dados qualitativos NVivo7, o qual permite conjugar tarefas mecânicas com tarefas conceituais.

\section{Procedimentos de análise}

$\mathrm{Na}$ primeira fase da análise de dados, procedeu-se à codificação da informação transcrita, organizando a informação recolhida em categorias conceituais, para dar cumprimento ao primeiro passo, de dotar os dados de uma estrutura lógica. Miles e Huberman (1994) referem que os códigos são etiquetas ou rótulos para designar unidades de significado para descrever ou inferir a partir dos dados compilados durante o estudo. Assegurou-se a validade dos códigos pelo cumprimento de três requisitos: 1) refletem aquilo que é objeto de pesquisa; 2) são mutuamente exclusivos, pois são distintos; 3) são exaustivos, porquanto todos os dados relevantes encaixam na grelha de codificação. 
Face às características do presente estudo, a generalidade das categorias de observação foram estabelecidas "a priori", sendo que apenas uma foi estabeleciada "a posteriori” (aparência), construída a partir do conteúdo de análise. A procura de um ponto intermédio entre os pólos indutivo e dedutivo foi considerada. Neste sentido, e segundo GoETz e LE COMPTE (1984), comparar, confrontar, agregar, ordenar, estabelecer relações e especular estão presentes no processo de análise de dados.

$\mathrm{Na}$ definição dos aspetos a considerar na representação da configuração de competência, teve-se por referência os pontos utilizados por HoNG e STÄHLE
(2005) num estudo acerca da coevolução do conhecimento e da competência na área da gestão, tendo sido definidos os seguintes pontos: orientação paradigmática, perspetivas e conceitos e assumpção de base.

\section{Categorias de análise}

No presente estudo, as categorias analíticas foram estabelecidas com base no modelo de competência profissional de CheEtham e Chivers $(1996,1998)$, composto por quatro "componentes nucleares" e por um conjunto de "fatores relacionados com a competência” (TABELA 1).

TABELA 1 - Modelo de competência de CHEETHAm e Chivers (1996, 1998): competências nucleares e fatores relacionados com a competência, às quais acresceu a categoria "aparência".

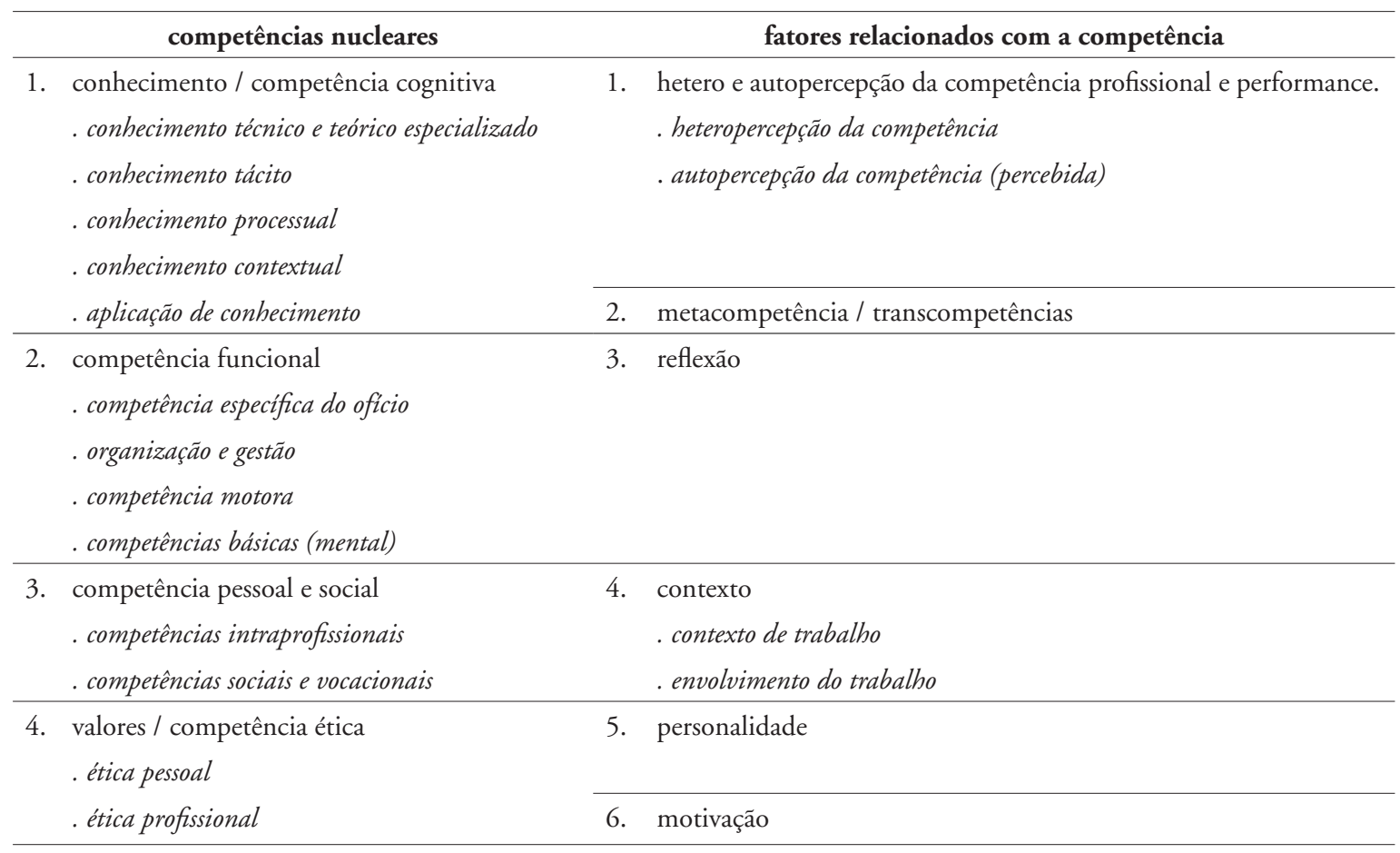

Para a análise dos dados, a unidade de registo adotada foi o parágrafo, e a interpretação lógico-hermenêutica foi utilizada como critério. Após a tarefa de codificação, procedeu-se a uma análise de caráter descritivo da prevalência das categorias e sub-categorias, como etapa preliminar da fase interpretativa, constituída por duas etapas: 1) análise das conceções explicitadas pelos profissionais de cada área ocupacional, na tentativa de detetar a unidade identitária de cada área; 2) análise transversal de todas as áreas ocupacionais, na tentativa de construir um "mapa conceitual" da área dos profissionais do desporto. Para uma apreensão mais rigorosa desta rede conceitual, teve-se em conta a expressão de cada categoria, tanto no conteúdo como no "peso", embora este último como indicador adicional. Para dar cumprimento às diferentes etapas, foi utilizado como referência o método sugerido por FraNKFoRT-NACHIMAS e NACHIMAS (1996), que estrutura a exploração dos dados a partir de um conjunto de questôes, permitindo uma apreensão mais profunda e rigorosa do conteúdo.

A fiabilidade foi testada na codificação de quatro entrevistas, uma de cada área ocupacional. Os procedimentos utilizados foram a percentagem de acordos e o índice de Kappa de Cohen. Os valores encontrados foram de elevada consistência: percentagem de acordos $=0,89 \%$ e $\mathrm{K}=0,849$, valores acima dos mínimos apontados pela literatura (FLEISS, 1981). 


\section{Resultados}

\section{Professor de educação física}

A diversidade de modos como os professores de Educação Física expressaram a sua ideia acerca do construto competência evidenciou discursos identificadores da ação docente, representando a maioria, e discursos inespecíficos, pouco identificadores da atividade profissional.

Relativamente às componentes nucleares, os professores de Educação Física possuem uma noção de competência sustentada nas componentes ética e de conhecimento ( $42 \%$ e $30 \%$ respetivamente), porquanto o professor é considerado um educador.

Na competência de conhecimento, as referências distribuem-se pelas categorias que a compõem, sendo o conhecimento oriundo da formação inicial (conhecimento específico) o mais referenciado (63\%); materializado, sobretudo, no conhecimento designado de "acadêmico" e "pedagógico", como ilustra o excerto EF13.

Tem que ter formação acadêmica e pedagógica. Se calhar sou capaz de te dizer que tem pelo menos que perceber que a determinado nível não pode ser a pedagogia a dominar a situação do conhecimento, e que o que precisa é formação. Para ser professor tem que ter formação superior, superior, quer dizer estar bem apetrechado e dominar aquilo que quer transmitir [...] [EF13, parágrafo 19].

O conhecimento tácito referencia-se sobretudo (41\%) às vertentes da experiência vivida e partilhada e, de forma acessória, às vivências de prática desportiva (excertos EF12 e EF14). Já a expressão das categorias conhecimento processual e contextual foi extremamente reduzida.

[...] isto da competência, se calhar, também vem com a experiência, desde que uma pessoa queira aprender com os próprios erros, de certeza que a experiência dá muito a ganhar [EF12, parágrafo 36].

[...] mas também tem a ver com a prática desportiva pessoal, prática desportiva pessoal e desportos que praticou, experiência pessoal, conhecimentos [EF14, parágrafo 18].

A competência pessoal e social mostrou ter um peso relevante (16\%). Os professores consideram que as relações interpessoais são a base de tudo, nomeadamente do processo de ensino-aprendizagem, traduzidas na capacidade de comunicar e de dialogar. A funcionalidade da relação interpessoal é referenciada como tendo que ser empática e revestida de um enfoque pedagógico (excerto EF26).
[...] mas consegue transmitir igualmente um entusiasmo, mas de um modo diferente que não sei muito bem traduzir por palavras, tem uma facilidade de comunicação muito grande com os alunos, domina muito bem aquilo que são os conteúdos ou disciplinas do programa [EF2, parágrafo 26].

A competência funcional apresenta menor expressão (12\%), sendo que as referências se consubstanciam na capacidade de executar, traduzida na intervenção técnica e, consequentemente, na formação geral dos alunos, como é invocado no excerto EF19.

Capacidade de executar, estar preparado para desempenhar uma determinada função, uma tarefa; executar essa tarefa bem, conseguir atingir os objetivos que estão definidos [EF19, parágrafo 6].

De entre os fatores relacionados com a competência, as metacompetências e a motivação são os que mais se destacam (33\% e 19\% respetivamente), sendo que a reflexão é pouco considerada (8\%). Enquanto as metacompetências, traduzidas na capacidade de adaptação e na criatividade, são enunciadas como ferramentas cruciais ao exercício profissional (excerto EF5), o gosto pela profissão é considerado o "motor" que despoleta e mantém a manifestação e o desenvolvimento da competência (excerto EF10).

No fundo, o que eu acho que é fundamental é a adaptabilidade, que é, sermos capazes de todos os dias nos adaptarmos às diferentes situaçôes [...] também termos capacidade de acompanhar e irmos sempre à procura de novos métodos, de novas metodologias, ou pelo menos no âmbito da organização didática e metodológica [...] [EF5, parágrafo 9].

É preciso ter paixão por aquilo que se faz, gostar daquilo que se faz, acho que não consigo conceber um professor competente se não gostar daquilo que faz, se não for profissional [EF10, parágrafo 9].

Os fatores contextuais são pouco valorizados. No fator percepção de competência, pese embora a parca expressão, duas ideias ganham corpo: a autoconfiança em relação à obtenção de resultados e a visibilidade dos resultados traduzida no sucesso dos alunos, sendo que a percepção dos outros é mais valorizada que a percepção de si próprio, como elucida o excerto EF8.

Um professor competente é aquele que faz com que os objetivos do ensino sejam, tenham algum sucesso junto dos alunos [EF8, parágrafo 9].

A visão geral dos resultados permite destacar que os professores de Educação Física possuem uma identidade 
profissional diluída e assumem como principal função a de educador. Ao nível do entendimento de competência, estes dão relevo à componente ética e de conhecimento, sendo que a funcional envolve as restantes componentes. Já ao nível dos fatores que influenciam a competência, a motivação e metacompetências assumem primazia, como está patente na FIGURA 1.
Relativamente à perspetiva de competência, são visíveis compósitos de duas perspetivas: a funcionalista e a personalista; a "ideia" de competência encontra-se mais próxima do funcionalismo ("worker-or-work oriented approach") do que do estruturalismo ("integrated approach to both worker and work").

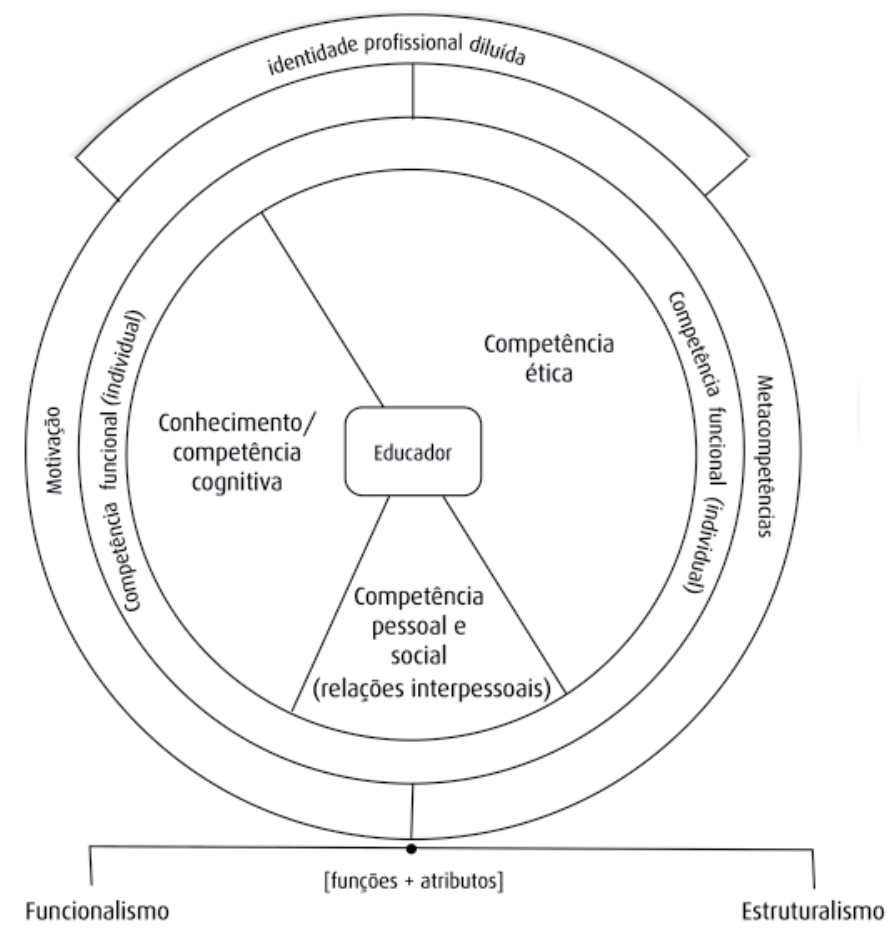

FIGURA 1 - Representação do entendimento de competência dos professores de Educação Física.

\section{Treinador}

Os treinadores atribuem primazia à competência de conhecimento (45\%) e à competência ética (31\%). A competência de conhecimento surge interligada com a funcional (9\%), porquanto os treinadores valorizam a articulação da formação com a capacidade de aplicar o conhecimento (competência especifica no oficio). Esta ideia é reforçada pelo fato da categoria aplicação de conhecimento se traduzir no saber transformar o conhecimento teórico em conhecimento "útil".

Não obstante, não existe unanimidade quanto à tipologia da formação, sendo que uns referem a necessidade de formação superior enquanto outros advogam que o importante é o conhecimento, não interessando a sua origem (excerto TR7).

$\mathrm{O}$ treinador, devido à especificidade da sua função, requer um conjunto de conhecimentos que terão que estar ao nível mais alto, portanto ao nível universitário, mas não necessariamente assim. É preciso de ter uma formação de nível científico elevado, se isso coincide com a universidade, é aí mas não necessariamente aí.

[TR7, parágrafo 21].

Na categoria conhecimento tácito, a experiência é valorizada tanto na vertente de ex-atleta como na experiência de terreno resultante da reflexão e da observação de treinadores competentes (excertos TR9 e TR2).

Um treinador não tem tanta bagagem a nível de saber "quando foi à água". Ou seja, eu fui atleta, não é? e sei, mais ou menos, quando... quando sofria, quando é que sofria, quando é que as séries custavam [...] [TR9, parágrafo 14].

[...] é importante que a experiência não seja só uma experiência, ou seja um acumular de anos do treinador, mas seja uma experiência refletida [TR2, parágrafo 19].

Já a categoria organização e gestão, pertencente à competência funcional, surge associada à gestão da equipe técnica e dos atletas e à antecipação do processo de treino através do planeamento. 
É necessário ter uma autodefinição em relação àquilo que é o trabalho global do próprio organismo [...] até em relação aquilo que é a nossa equipe técnica, em que temos que ter tudo bem previamente definido em relação ao que cada um deve fazer, com [chefia] mas em autonomia, [...]. Depois, com mais ou menos diálogo entre nós, nós procuramos todos os dias, conversar tudo aquilo que é a ideia de cada e aplicá-las [TR10, parágrafo 15].

A competência ética tem peso relevante (31\%) e surge associada à competência pessoal e social (15\%); a competência ética materializa-se no rigor, na disciplina e no respeito pelo atleta como individualidade (excerto TR10). Já na competência pessoal e social, é a categoria competência intraprofissional que sobressai, consubstanciada na necessidade de se trabalhar em equipe e no respeito pela autonomia de cada elemento em relação à função que desempenha (excerto TR5).

Mas, eu diria que ser tolerante, aliás, a liderança de uma forma justa, é um aspecto fundamental [...] colocar regras normais, transparentes, simples, para que não as vejam, digamos, como uma forma de pressão, de ditadura [TR10, parágrafo 39].

Porque, ao fim e ao cabo, é uma modalidade individual, mas que temos que trabalhar em equipe, tanto em treinos como até em situaçōes de competição; porque, ao fim e ao cabo, o treinador e o atleta formam uma equipe, não é? [TR5, parágrafo 8].

Nos fatores relacionados com a competência, as categorias hetero e autoperceção da competência e motivação assumem a supremacia (46\% e 17\% respetivamente). A associação entre rendimento desportivo (traduzido nas menções aos resultados, rendimento, sucesso e alcançar objetivos) e competência ganha relevo (excerto TR3). No fator motivação, o gosto e a paixão pela modalidade emergem como fundamentais. Compósitos visíveis no excerto TR9.

Treinador competente para mim é aquele que tem resultados, é a primeira coisa; mas, acima de tudo, é um treinador que dentro desses resultados consegue, consegue criar, uma filosofia de trabalho e de treino entre os atletas, que permite perspetivar o alto rendimento [TR3, parágrafo 12].

O gosto, sem dúvida, da modalidade, porque ... eu gosto, se não não vinha, não é? São horas extras que embora sejam pagas, mas não são pagas como deviam ser, por isso, é o meu gosto pela modalidade [TR9, parágrafo 17].
Ao nível dos fatores metacompetências e reflexão, o número de referências não é elevado (18\% e 17\% respetivamente). Na categoria metacompetências, emerge a noção de "maleabilidade", resultado da harmonização entre adaptação e flexibilidade. Já a reflexão é considerada importante tanto na aquisição como no desenvolvimento da competência.

A plasticidade, a inteligência, a facilidade de questionar sempre as coisas, nunca aceitar nada como certeza e, enfim, o princípio da análise. Portanto, acho que nesse aspeto, embora não especificamente, me marcou bastante [TR14, parágrafo 22].

À categoria aparência é concedida uma expressão reduzida; no entanto, a forma como o treinador se apresenta perante os mídia é um fator de promoção ou despromoção da sua competência (excerto TR16). Os fatores contextuais são também pouco referidos e estão circunscritos às condiçôes locais em que decorre à ação e o envolvimento social dos atletas e do treinador.

No mundo atual, um dos problemas com que nós nos debatemos tem muito a ver com os media, com a comunicação social. Eles, para nós, são um grande problema [...]. E hoje são fundamentais a imagem [...] Há fatores que pesam imenso na comunicação social e que muitas vezes transportam cá para fora imagens que muitas vezes não são reais [...] [TR16, parágrafo 41].

Terá que ter uma noção de todo o envolvimento social que o rodeia, e aquilo, ou seja, aquilo que influencia a atividade dele, e aquilo que poderá influenciar através do seu comportamento e através do seu desempenho [TR15, parágrafo 20].

Em síntese, os treinadores denunciam uma identidade profissional consistente e atribuem ao treinador o papel de formador e gestor. O entendimento de competência encontra-se fortemente apoiado na competência de conhecimento e ética, sendo que a competência funcional surge em íntima associação com as restantes componentes nucleares. Ao nível dos fatores associados à competência, a percepção dos resultados, motivação e metacompetências assumem-se como muito relevantes (FIGURA 2).

A perspectiva integrada de competência marca presença; contudo, não obscurece por completo a emergência de traços da perspectiva behaviorista, na qual o resultado final ("output") ocupa um papel central. A maior proximidade ao estruturalismo ("integrated approach to both worker and work”) começa a vislumbrar-se, todavia não se confirma totalmente. 


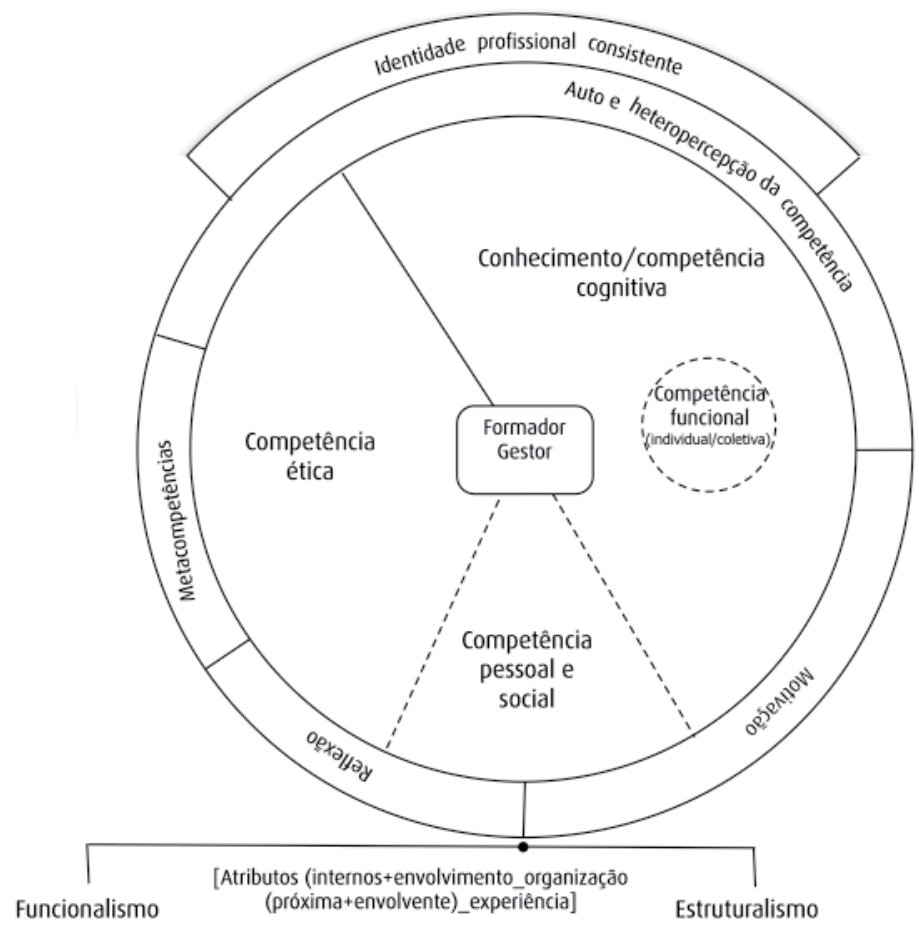

FIGURA 2 - representação do entendimento de competência dos treinadores.

\section{Profissional de atividade física adaptada}

A competência de conhecimento assume primazia (39\%), seguida da competência pessoal e social e competência ética (33\% e $23 \%$, respetivamente). A competência funcional tem menor relevo (5\%). Ao nível da competência de conhecimento, a categoria conhecimento especializado é a mais relevante, pela necessidade de formação específica em relação à obtida em EF e Desporto. Na categoria conhecimento tácito, a experiência oriunda do aprender com os erros e do aprender com os outros é referida como fonte de conhecimento (excerto AD12).

Para mim, a melhor característica é a experiência, e eles já terem vivido as experiências e adaptaram-se e conseguiram resolver. E eu também passo por elas e tenho os meus erros e tento melhorá-los. [AD12, parágrafo 38].

As referências ao conhecimento processual centramse no conhecimento dos meios, que se traduz na resposta a três questóes da didática: o quê? o como? e a quem? Este surge bastante associado à categoria aplicação de conhecimento. $\mathrm{O}$ conhecimento contextual, embora pouco referido, aponta a necessidade de se conhecer as infraestruturas e o contexto social da instituição e da população (AD4).

Perceber o contexto social, ter atenção também não só aquele espaço, aquela hora de aulas, mas também estar atento ao contexto social de onde as pessoas provêm, também explica muito da sua postura, das suas necessidades. [AD4, parágrafo 24].

$\mathrm{Na}$ competência ética, a ética profissional destaca-se (65\%) e relaciona-se com o cumprimento de horários e a atualização. $\mathrm{Na}$ categoria ética pessoal, as questões sociais e vocacionais são as mais valorizadas, aspeto reforçado quando na categoria personalidade, pelo destaque da paciência e da boa-disposição, envolvidas numa grande dose de afabilidade e de compreensão como traços essenciais.

Tem que ter uma certa sensibilidade, porque não é qualquer pessoa que pode trabalhar com este tipo de população, não é? Tem que ter uma certa sensibilidade para encarar os problemas das pessoas, o seu dia a dia [AD7, parágrafo 8].

A competência pessoal e social surge interligada com a competência funcional, remetida para o disponível sobretudo ao nível mental e afetivo; nas competências sociais e vocacionais e na competência específica do oficio, o fazer bem é relevado, onde o ser flexível e adoção de uma postura "pedagógica" são valorizadas. Já na competência funcional, a organização e gestão surge associada à necessidade de antecipação do processo de ensino, consubstanciado no conhecimento das condições (materiais e humanas) e no planeamento.

Nos fatores relacionados com a competência, as metacompetências, a motivação e a personalidade são as mais valorizadas, onde a capacidade de adaptação, aliada à criatividade e perspicácia é valorada. 
O ser capaz de se adaptar a novas situações, ... essencialmente mais essa, porque na adaptação, às situaçôes que nos surgem, por muita experiência que uma pessoa tenha, tem sempre que se adaptar. [...] ea curiosidade e a criatividade é muito importante, para ajudar a isto, a descobrir as estratégias, as melhores estratégias, para se chegar onde é preciso, aquilo que eles precisam mesmo [AD27, parágrafo 9].

Os fatores motivacionais são muito importantes, onde o gostar, aliado à motivação, interesse, satisfação são salientados, quando suportados em conhecimentos.

Posso não falar em incompetência, posso falar mais em boa vontade. Há muita gente com muito boa vontade, não é? Penso que há muitos colegas com muito boa vontade, tentar ajudar, tentar fazer alguma coisa por este tipo de populações. Só que, claramente, aquilo que tem, enquanto formação inicial, não lhes é suficiente para desenvolver atividades com segurança. [AD20, parágrafo 17].

As referências ao contexto são pouco expressivas e reportam-se ao momento atual que a sociedade atravessa, à influência do contexto social de proveniência dos alunos e à rede mais próxima de influência constituída pelas condições locais onde a atividade se desenrola. A percepção dos outros (heteropercepção) e a percepção de si próprio (autoperceção) são pouco valoradas assim como a reflexão.
Em suma, estes profissionais possuem identidades profissionais distintas, em consonância com a sua atividade profissional principal (ensino ou treino), sendo que o profissional de Atividade Física Adaptada é visto como um auxiliar, um conselheiro. A sua representação de competência é sustentada na competência pessoal e social, suportada pela competência de conhecimento e ética. Já a competência funcional é pouco expressiva. Ao nível dos fatores, a motivação, personalidade e metacompetências são traços indeléveis da noção de competência (FIGURA 3).

A ênfase colocada nos aspectos relacionais, centrados nos atributos pessoais do profissional, remete para uma representação de competência atomista, circunscrita a aspetos "humanistas". No que concerne à orientação paradigmática, a "ideia" de competência situa-se mais próxima do foco interpretativista, porquanto a valorização da relação trabalhador vs trabalho e da experiência "vivida" está bem presente. Relativamente à perspetiva de competência é a personalista que emerge, sendo que a representação de competência se situa num lugar intermédio entre o funcionalismo e o estruturalismo, pois, apesar dos recursos individuais ser central, a capacidade de gerir recursos também está presente.

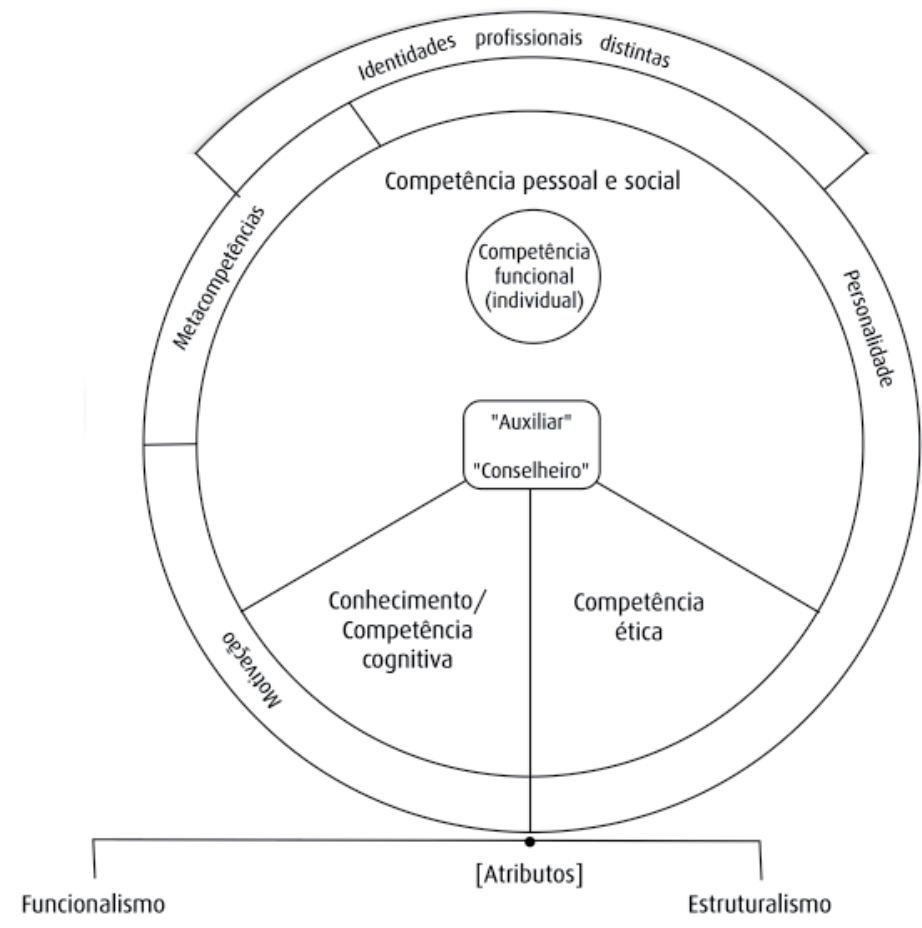

FIGURA 3 - Representação do entendimento de competência dos profissionais de Atividade Física Adaptada. 


\section{Profissional de "fitness"}

A competência de conhecimento e ética assumem a maior relevância (33\% e 30\% respetivamente) entre os profissionais de "fitness", sendo a ética profissional que recolhe o maior número de menções. A competência pessoal e social assume relevância similar à competência ética e competência de conhecimento. Ao nível da categoria ética profissional, a necessidade de atualização constante e o profissionalismo, associado à pontualidade, à assiduidade, ao rigor e à organização, marcam presença. A categoria ética pessoal tem menor relevância e funde-se no saber estar e nas relações interpessoais com o cliente (excerto FI16).

Profissionalismo. Cumprir os horários. Evoluir em tudo e nunca estagnar. Há sempre coisas a aprender [FIFB12, parágrafo 6].

Ter a sensibilidade para ver os problemas que o cliente tem [FI16, parágrafo 9].

$\mathrm{Na}$ competência de conhecimento, o conhecimento especializado é o mais valorizado. A formação acadêmica, apesar de ser maioritariamente aceite como necessária, é desvalorizada por alguns que consideram ser suficiente possuir uma formação específica; já outros consideram a formação específica como complemento à formação acadêmica (excerto FI30). A tipologia de conhecimentos, à exceção dos conhecimentos técnicos e pedagógicos, difere de acordo com a especificidade da área de intervenção (cárdio-fitness, ginástica de grupo, etc.).

A formação e o conhecimento têm que estar sempre presentes, a licenciatura ou o que quer que seja. Depois, também pode investir através de livros, de ações de formação, de vídeos e isso tudo. Mas um requisito fundamental tem que ser esse, a formação [FI30, parágrafo 18].

$\mathrm{Na}$ categoria conhecimento tácito, a experiência é valorizada e circunscreve-se a três fontes: experiência profissional (prática ou pedagógica), vivência de prática desportiva e aprendizagem com outros mais experientes. A categoria conhecimento processual é expressiva e reportase ao conhecimento dos meios, mais especificamente, da garantia da segurança. Também a categoria aplicação de conhecimento assume um valor expressivo e materializase na expressão "sabe o que está a fazer". O ser capaz de passar o conhecimento, aplicar e adaptar são outros aspetos referenciados (excerto FI13). O conhecimento contextual é pouco referenciado e remete para a resposta satisfatória a dar sempre ao cliente.

E experiência profissional, seja ela na parte prática, seja na parte pedagógica [FI24, parágrafo 9].
Que demonstre em todas as aulas que sabe porque está a fazer as coisas. É que nós também temos muitos clientes a testar-nos nesse aspecto, porque fazemos isto? Porque muitas vezes eles sabem, são médicos, e nós temos de saber. Um bom professor tem de ter estas qualidades [FI13, parágrafo 12].

A competência pessoal e social surge associada à competência funcional (20\% e 14\% respetivamente), baseada em aspectos relacionados com o respeito pelas normas profissionais e colegialidade, onde a capacidade de trabalhar em equipe é encarada como fundamental ao desenvolvimento pessoal e da organização. Ao nível da competência funcional, a gestão dos recursos humanos é referida mormente a capacidade de organização, o ser capaz de responder às demandas dos clientes, e a partilha e entreajuda entre os profissionais.

E por isso é que tem os professores que cá têm e o trabalho de equipe que temos feito. As coisas partem de nós e se tivermos iniciativa e formos proativos, com um bom trabalho de equipe, as coisas conseguem andar para a frente [FI21, parágrafo 25].

Saber fazer e também ter um boa gestão das pessoas e das motivaçôes, daquilo que as move para as trazer aqui. Boa gestão de recursos humanos [FIMB9, parágrafo 12].

Ainda ao nível da competência pessoal e social, a categoria social e vocacional é a mais relevante, sendo que a qualidade das relaçóes corporiza o centro das referências (relação professor/aluno e relação professor/com os outros sujeitos que "coabitam" no mesmo local de trabalho). Ao nível dos restantes fatores, os que mais se evidenciam são a personalidade, as metacompetências e a motivação, sendo que a aparência também assume um lugar de destaque. De entre as características mais mencionadas, a simpatia e o carisma destacam-se.

Tem a ver muito com o carisma. Com o prender. É a diferença. Provavelmente a sala dele está cheia e a do outro que é tão ou mais competente, e tem a mesma formação, não está. É uma questão de carisma, de show, espetáculo [FI7, parágrafo 24].

As referências ao fator metacompetências estão marcadas pela busca de conhecimento e pela capacidade de analisar e tomar decisóes; estar aberto ao conhecimento e incorporar novas ideias são relevados. É tipo uma biblioteca de conhecimento; ou seja, uma pessoa que não se cansa de querer saber mais. E qualquer pergunta que tenha é a pessoa a quem recorro neste momento, porque tenho 
a consciência que se tiver alguma dúvida, se ele não souber, amanhã está-me a dizer, "espera aí, não tenho a certeza...” [FI8, parágrafo 23].

Não obstante os fatores motivacionais serem pouco referidos, a motivação intrínseca é saliantada. A aparência surge como uma marca forte, onde o aspeto saudável do ponto de vista físico é salientado. Pese embora as categorias dos fatores de natureza contextual serem pouco referenciados, o conhecimento do contexto e a adaptação do comportamento às características contextuais, nomeadamente às exigências do "cliente" são mencionadas.

Em função disso, nós podemos gerir melhor o contexto, mas aquilo que vemos na sala de musculação é que a maioria das pessoas precisa de atenção [FI27, parágrafo 18].

O fator percepção da competência (hetero e auto) revelou uma expressão diminuta e remete para a obtenção de resultados, relativizada ao tipo de população. A reflexão não assume relevo. Em síntese, a ideia de competência que os profissionais de "fitness" possuem está envolta, de forma bastante equilibrada, em três componentes nucleares da competência: a competência ética, competência pessoal e social e competencia de conhecimento.

A perspetiva integrativa de competência assume visibilidade, existindo abertura e integração de elementos, cuja "funcionalidade" só é possível se houver conjugação. Fatores, como as metacompetências, a motivação, o contexto próximo e de envolvimento, relacionam-se de forma harmoniosa. A competência é construída sobretudo através das práticas, dos investimentos da organização e do profissional. Definitivamente, mas não categoricamente, o estruturalismo tem presença acentuada na "ideia" de competência do profissional de "fitness".

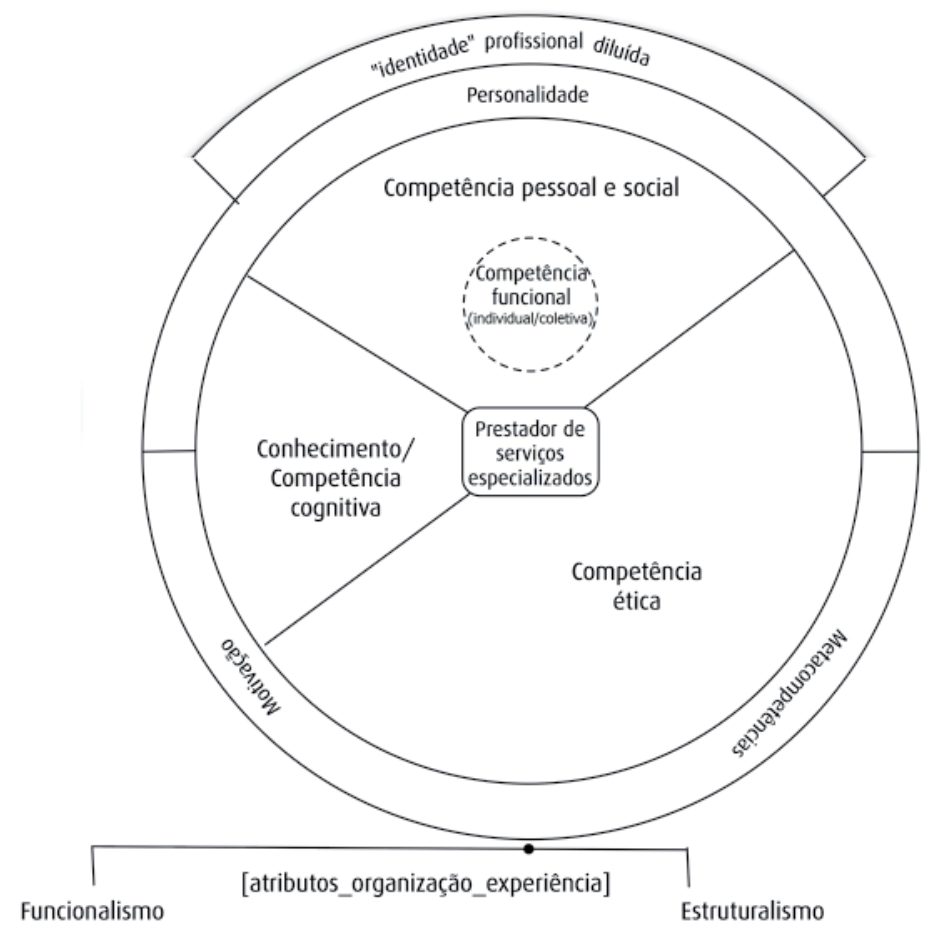

FIGURA 4 - Representação do entendimento de competência dos profissionais de Fitness.

\section{Discussão}

A natureza multidimensional, relacional e situacional da competência, reconhecida por vários autores (e.g., Gonzi, HaGer \& Athanasou, 1993; Hager \& GonZI, 1996; Stoof, Martens, Merriënboer \& Bastiens, 2002; Velve, 2000; WeINERT, 2001), encontrou eco neste estudo. A ideia de competência associada à identidade do campo do profissional do desporto, através de contributos específicos que conferem diferenciação a cada contexto e acrescem compósitos à matriz conceitual comum de competência, foi a nota dominante. A FIGURA 5 apresenta um quadro sinótico caracterizador desta matriz pela agregação das particularidades de cada área profissional, representativa das relações entre a noção de competência e as diferentes áreas profissionais. 


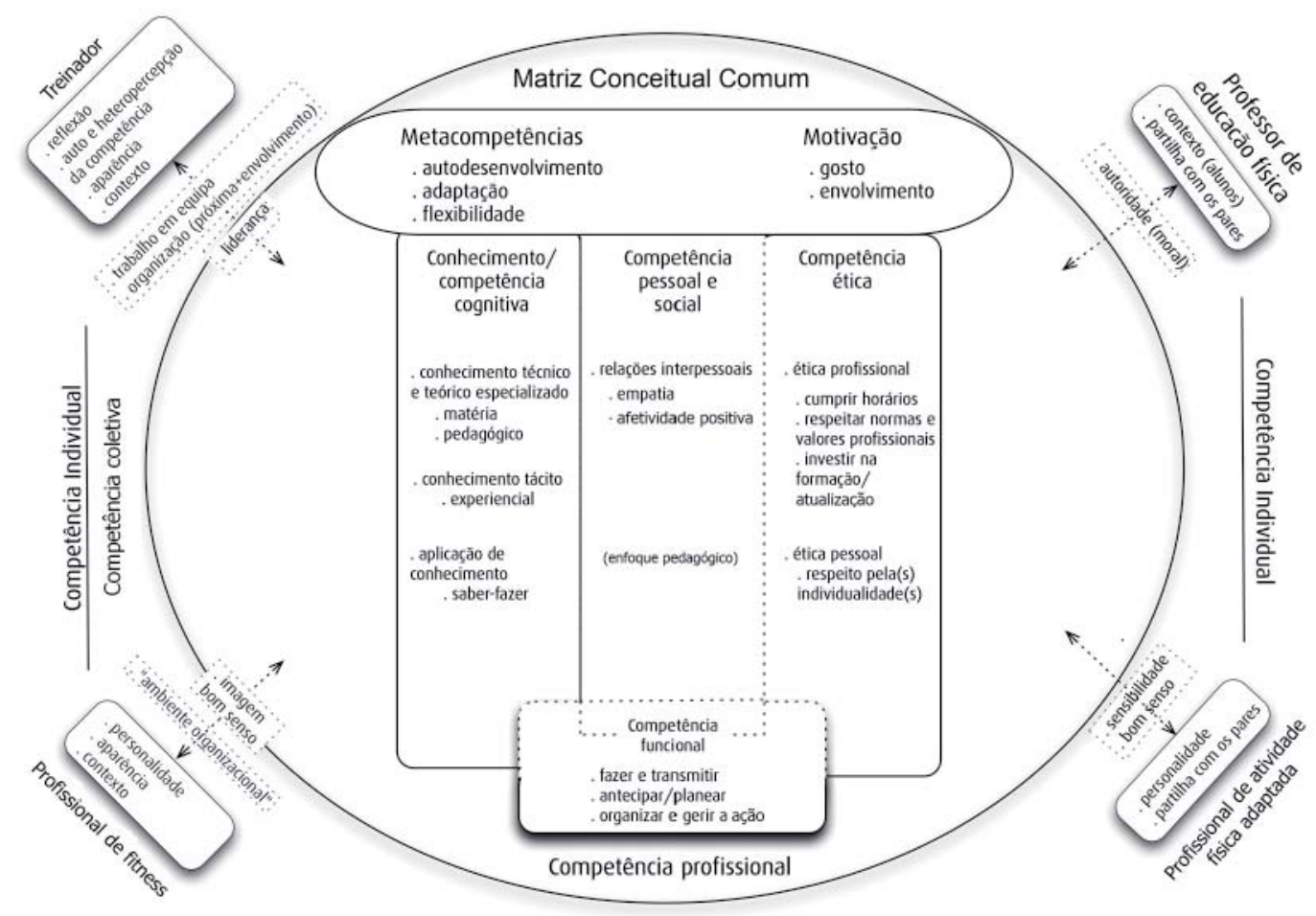

FIGURA 5 - Representação dos pontos comuns eespecificidades da representação decompetência dos profissionais do desporto.

A FIGURA 5 denota que a competência de conhecimento e a competência ética são centrais no entendimento de competência do profissional do desporto. Neste sentido, independentemente da profissão exercida, os profissionais do desporto inquiridos consideram essencial adotar uma postura ética (profissional e pessoal), para além de ser absolutamente necessário possuir conhecimento especializado, tácito e de aplicação. Já a competência pessoal e social surge em estreita articulação com a competência ética, onde as relaçôes interpessoais se revestem de enfoque pedagógico. Emerge ainda que a competência funcional está intimamente ligada às restantes componentes nucleares da competência para além das metacompetências e a motivação serem reconhecidas como sustentáculos da competência reiterando o defendido em distintas áreas profissionais, nomeadamente do campo organizacional (SPENCER \& SPENCER, 1993) e do mercado de trabalho (Cheetham \& Chivers, 1998; Le BOTERF, 1994).

Em termos dos contributos de cada área profissional, o treinador adiciona aos fatores de "sustentação" da competência os fatores de reflexão e de percepção da competência profissional, atribuindo-lhes o papel de "reguladores", pois permitem (re)aferir e alterar formas de preparar, de estar e de atuar. Já o contexto próximo e o envolvimento são assumidos como fatores que condicionam o desempenho, enquanto a liderança é antevista como elemento distintivo no exercício competente. Relativamente ao profissional de "fitness", os fatores de personalidade, a aparência e o contexto surgem como elementos coadjuvantes das competências nucleares, sendo o ambiente organizacional e imagem fatores valorizados.

A noção de trabalho em equipe e de envolvimento organizacional apenas está presente no discurso dos treinadores e dos profissionais de "fitness". Já os profissionais de Atividade Física Adaptada e os professores de Educação Física salientam a partilha de conhecimento, de ideias com os pares, sublinhando o fato dos profissionais de Adaptada atribuírem relevância às características da personalidade relacionadas com afetividade.

Deste modo, a matriz conceitual de competência do profissional do desporto encontrada apresenta sobretudo uma perspetiva integrativa, na medida em que as diversas componentes se inter-relacionam (e.g., Cheetham \& Chivers, 1998; Gonzi, 1994; Hager \& GonZI, 1996; Velve, 2000; Weinert, 2001). Não obstante esta interrelação, a representação de competência não incorpora todas as componentes consideradas como relevantes ao exercício competente, como é o caso da reflexão. Por conseguinte, os traços de 
natureza estruturalista, evocados por Hong e STÂHLE (2005) e evidentes nos profissionais do treino e do "fitness", não são assumidos pela generalidade dos profissionais do desporto; por exemplo, a ausência da noção de competência coletiva, considerada já em 1994 por LE BOTERF como elemento fundamental à manifestação da competência, não é considerada.

\section{Competência de conhecimento}

O papel central do conhecimento no conceito de competência, patente neste estudo, surge em múltiplas áreas, nomeadamente ao nível da formação de professores (Flash, 1986; Grossman, 1990; SHUlman, 1987) e de treinadores (Jones, 2006; Santos, Mesquita, Graça \& Rosado, 2010). Não obstante o conhecimento ser um elemento necessário à competência, este não é sinônimo de competência (PEARSON, 1984; Perrenoud, 1999), ideia esta que também ficou bem patente neste estudo, porquanto a ideia de que o conhecimento terá de se revestir de uma postura ética e da capacidade para transmitir (competência funcional) é reconhecida no desempenho competente.

Outro aspecto relevante é a noção de que a competência está envolta em diversos tipos de conhecimento relacionados, que advêm da ação teórica (conhecimento teórico especializado) e da ação prática (conhecimento tácito, experiencial). Esta noção vem corroborar a perspetiva de SANDBERG (2001), que considera que o conceito de competência, utilizado pragmaticamente, é uma combinação do conhecimento, da experiência e das capacidades pessoais.

Ainda dentro deste quadro conceitual emergente, o conhecimento da matéria e o conhecimento pedagógico são considerados sustentáculos do conhecimento técnico e especializado. Neste sentido, sendo o ensino uma atividade complexa exige conhecimentos nos mais diversos domínios (GRAÇA, 1999), ideia corroborada no domínio do treino (SANTOS et al., 2010). Por sua vez, Crum (2001, p.67) indica que “a formação no âmbito pedagógico do conteúdo é definitivamente a competência essencial para o professor de Educação Física.”

De salientar ainda que os inquiridos consideram que é vital aliar a experiência à sensibilidade, sendo que estas conexões são compreensíveis à luz das referências de autores como DALL'Alba e SANDBERG (1996) e SANDBERG (1994, 2000, 2001). Quanto à aplicação de conhecimento, o discurso da racionalidade prática (SCHÖN, 1983) é dominante, porquanto a conceção que prevalece é de que o conhecimento não tem uma aplicação direta na prática, sendo necessário transformá-lo, ajustá-lo de forma a torná-lo compreensível; o conhecimento provindo da prática remete para um entendimento situacional de competência manifestado na ação.

Deste modo, parece assim ficar evidente que os processos de formação devem ser capazes de tornar a aprendizagem situada e integrativa. Neste âmbito, é indispensável que a ação "teórica” e "prática” caminhem lado a lado, precursores do desenvolvimento de pensamento flexível e capacitante da resolução de problemas (BATISTA, 2008). Lester (1995, p.3) acrescenta que os profissionais têm de estar aptos para decidir "which knowledge and which logic to use as well as how to use it" e KIRSHHNER et al. (1997) referem que lidar com o inesperado e o imprevisível criativamente é uma componente crítica do conceito de competência. Os treinadores do presente estudo referem que o conhecimento tácito advém sobretudo da experiência vivida e partilhada e, acessoriamente, das vivências de prática desportiva, corroborando o estudo de Gould, Giannini, Krane e Hodge (1990), no qual 130 treinadores Americanos concluíram que o conhecimento experiencial e a educação informal são essenciais no seu desenvolvimento profissional.

\section{Competência ética}

As representações dos inquiridos vêm de encontro à generalidade dos modelos de competência que englobam as competências éticas, sob as mais diversas designações [e.g. traços (SPENCER \& SPENCER, 1993); atitudes (WESTERA, 2001); ética, valores (CHEETHAN \& Chivers, 1996, 1998) e moral (Formosinho, 2001)]. Apesar da relevância ser transversal, é passível de se percecionar ênfases algo diferenciadas em função da área profissional. Ao nível dos professores, a noção de autoridade reconhecida eclode dos discursos, sendo que este tipo de autoridade é designado por EsTRELA (1997) de autoridade moral. Segundo EsTRELA (1997, p.164), “(...) ser educador obriga a um modo particular de ser e estar, obriga a uma autoridade moral". Por conseguinte, a noção de que o professor é um educador que deve consignar uma dimensão ética à sua ação, balizada por critérios deontológicos, ficou bem expressa no discurso dos professores. Já nos treinadores, o profissionalismo, assente no rigor e disciplina, tem primazia, sendo que na componente ética pessoal, o respeito pelo atleta aliado à justiça na liderança são considerados requisitos fundamentais (Aronowitz \& Giroux, 1985; SCHEMPp, TeMPLETON \& ClARK, 1998). No que concerne aos profissionais de "fitness", a noção de ética pessoal está adstrita às 
relações interpessoais onde o respeito pelo cliente e a capacidade de ouvir são essenciais. A vertente pragmática é nota dominante porquanto a relação de respeito apela à diferenciação em função dos alunos/ clientes e da situação (Perrenoud, 1995).

\section{Competência pessoal e social}

A competência pessoal e social, consubstanciada nas relaçôes interpessoais, interpenetra as restantes componentes nucleares, sendo que as ligaçóes mais relevantes ocorrem com as competências ética e funcional. A interação identificada entre estas componentes remete para um entendimento integrativo de natureza interpretativa de competência, no qual os diferentes compositos resultam do modo como cada sujeito apreende as suas vivências na interação com outros, remetendo para as conceitualizações de competência de natureza interpretativa e relacional (SANDBERG, 1994; VelVE, 2000). Os inquiridos consideram ainda que as relaçóes interpessoais se devem pautar pela empatia e afetividade, associadas aos aspetos de natureza ética, onde ganham um caráter pedagógico. No mesmo sentido, no modelo genérico de competências para trabalhadores de serviços humanos, as relações interpessoais assumem primazia (SPENCER \& SPENCER, 1993).

\section{Competência funcional}

A competência funcional surge em íntima articulação com a competência de conhecimento, fundada na relação da "ação teórica " com a "ação prática", tanto no âmbito do ensino como do treino. Deste modo, a capacidade de comunicar e de transformar o conhecimento do conteúdo em conhecimento pedagógico é assumida como nuclear à função patente nas propostas de qualificação dos treinadores à escala Europeia (DufFy, 2008) e em Portugal (Instituto de Desporto de Portugal - IDP, 2010).

Os treinadores acrescem à sua função o papel de "gestor", porquanto consideram a complexidade dos ambientes onde atuam. Neste âmbito, WALLACE e Pocklington (2002) e Armour e Jones (2000) avançam com o conceito de "orquestração" para interpretar a complexidade do processo de treino, salientando que é uma atividade que envolve um conjunto alargado de parâmetros, os quais pretendem responder às exigências e contingências afetas à atividade do treinador (JONES \& WALLACE, 2005).

\section{Fatores relacionados com a competência}

Relativamente aos fatores relacionados com a competência, as metacompetências e a motivação assumem o papel de "sustentação" da competência, sendo que o gosto é entendido como fator mobilizador da continuidade do envolvimento na profissão. No que concerne às metacompetências, o autodesenvolvimento, a capacidade de adaptação e a flexibilidade são requisitos indicados como necessários ao exercício competente, principalmente nos professores de Educação Física e treinadores. Como advoga BarnetT (1994), uma parte crítica do conceito de competência perfilha-se na capacidade de lidar com o inesperado de uma maneira criativa. Sendo estes elementos apontados como compósitos fundamentais à sobrevivência em campos profissionais complexos, como éa guerra, é natural que estes tenham emergido de sobremaneira no discurso dos treinadores, porquanto no campo do desporto a imprevisibilidade e a situacionalidade são marcas indeléveis. É de assinalar que os aspetos mais relevados confluem para a noção de "maleabilidade", que concilia a adaptação com a flexibilidade. $S_{C H O ̈ N}(1987)$ refere que a reflexão é particularmente importante em contextos complexos, apanágio dos contextos de ensino e de treino.

A reflexão, com exceção dos treinadores, é pouco valorizada pelos profissionais enquanto capacidade crucial para desenvolver as metacompetências, aspecto este que diverge da maioria dos modelos de competência profissional que tendem a incorporá-la. Cheetham e Chivers $(1996,1998)$ atribuem-lhe mesmo o estatuto de supermeta. ARGYRIS e SCHÖN (1974) referem que para um profissional ser competente necessita de refletir acerca da sua ação, para assim poder aprender com e através dela.

Por seu turno, os fatores motivacionais são percecionados como fundamentais pelos inquiridos das quatro áreas. Com efeito, o gostar, aliado à motivação, interesse, satisfação, é um dos temas termos mais mencionados. Tal como CheEtham e Chivers (1996, 1998), que incorporam a motivação no seu modelo de competência, WiLlis e Dubin (1990) referem a motivação como um fator importante da competência. Sob este ponto de vista, a aliança dos fatores motivacionais à noção de competência confere-lhe uma maior abrangência, fazendo parte, segundo KouwenHOven (2003), das descriçōes de competência mais elaboradas. 


\title{
Conclusões
}

Os profissionais do desporto revelaram uma representação de competência suficientemente consistente que, não obstante alguns contornos menos definidos, remete para uma matriz conceitual de competência de natureza multidimensional, relacional e situacional. Nesta matriz, as questôes de natureza ética e o enfoque pedagógico da profissão são os compósitos que parecem harmonizar e agregar o campo profissional. A competência de conhecimento e a competência ética, secundadas pela competência pessoal e social em íntima articulação com a competência funcional, assumiram-se como os vetores estruturantes da matriz conceitual de competência destes profissionais, sendo que as metacompetências e a motivação emergiram como esteios da competência.

Relativamente a cada área profissional, é de destacar que a representação de competência dos professores de Educação Física, pese embora sejam visíveis compósitos da perspetiva funcionalista e personalista (ênfase no saber fazer e nas questōes relacionais), se encontra mais próxima do funcionalismo. Já no treinador, é a perspectiva integrada que prevalece (grande relação entre as várias componentes da competência), embora sejam visíveis traços da perspectiva funcionalista. Neste grupo profissional, a maior proximidade ao estruturalismo parece evidente, tal como nos profissionais de "Fitness", em que a competência é vista como algo que é criado e construído através das práticas e não apenas como um conjunto de recursos pré-existentes. Por último, nos profissionais de Atividade Física Adaptada, a perspectiva personalista marca presença (a afetividade assume primazia), sendo que a representação de competência se situa num lugar intermédio entre o funcionalismo e o estruturalismo. Para além disso, e tendo em conta que as questōes pedagógicas trespassam as quatro áreas profissionais, o presente estudo aponta para a necessidade de, independentemente da tipologia da formação, ser necessário que as competências éticas e as competências pessoais e sociais sejam assumidas como sustentáculos do processo formativo, o qual, por sua vez, deve permitir a apreensão da dimensão situacional da competência.

\begin{abstract}
Representations of the sport workers over the concept of professional competence

The intervention field of the sports professional has become broader and more complex. Traditional occupations related to education and coaching have transformed and increased, bringing more difficulties to the already difficult conceptualization of professional competence. In this study we tried to understand the conception of professional competence that sports professionals have in the pursuit of identifying a conceptual map across the four occupational areas: Physical Education, Coaching, Fitness and Adapted Physical Activity. We interviewed 120 professionals (30 of each occupational area) about the understanding of competence and competent professional. Data analysis used procedures of content analysis. The results show us the fragile structure that still characterizes the field of the sports professional, although common traits come to the surface, starting to reveal a unique identity centred on knowledge and ethics competence seconded by personal and social competence in close connection with functional competence. Metacompetencies and motivation are highly valued factors and act as warrants of professional competence.
\end{abstract}

UnITERMS: Competence representation, Sport occupational areas, Professional competences.

\section{Referências}

ARGYRIS, C.; SCHÖN, D. Theory in practice: increasing professional effectiveness. San Francisco: Jossey Bass, 1974. ARMOUR, K.; JONES, R. The practical heart within: the value of the sociology of sport. In: JONES, R. (Ed.). Sociology of sport: theory and practice. London: Adison Wesley Longman, 2000. p.1-10. 
ARONOWITZ, A.; GIROUX, H. Education under siege: the conservative, liberal and radical debate over schooling. South Hadley: Bergin \& Garvey, 1985.

BARNETT, R. The limits of competence: knowledge, higher education and society. Bucckingham: SRHE \& Open University, 1994. BATISTA, P. Discursos sobre a competência: contributo para a (re)construção de um conceito de competência aplicável ao profissional do desporto. 2008. Dissertação (Doutorado) - Faculdade de Desporto, Universidade do Porto, Porto, 2008. BATISTA, P.; GRAÇA, A.; MATOS, Z. Competencia: entre significado y concepto. Contextos Educativos, Logroño, v.10, p.7-28, 2007.

BENTO, J. (Ed.) Contextos da pedagogia do desporto. Lisboa: Livros Horizonte, 1999.

BURGOYNE, J. The competence movement: issues, stakeholders and prospects. Personnel Review, Bradford, v.22, p.6-13, 1993.

CHEETHAM, G.; CHIVERS, G. Towards a holistic model of professional competence. Journal of European Industrial Training, Limerick, v.20, n.5, p.20-30, 1996.

. The reflective (and competent) practitioner: a model of professional competence which seeks to harmonise the reflective practitioner and competence-based approaches. Journal of European Industrial Training, Limerick, v.22, n.6/7, p.267, 1998.

CRUM, B. The "idola” of sport pedagogy researchers: les sophismes des chercheurs en psychologie du sport. Quest, Champaign, v.53, n.2, p.184-91, 2001.

DALLALBA, G.; SANDBERG, J. Education for competence in professional practice. Instructional Science, Dordrecht, v.24, p.411-37, 1996.

DUFFY, P. Implementation of the Bologna process and model curriculum development in coaching. In: PETRY, K.; ESTRELA, M. Viver e construir a profissão docente. Porto: Porto, 1997.

FLACH, H. (Ed.). Zur Entwicklung des Pädagogischen Könnens in der Lehrerausbildung. Berlin: Volk und Wissen Volkseigener Verlag, 1986.

FLEISS, J. Statistical methods for rates and proportions. 2nd.ed. New York: Wiley, 1981.

FORMOSINHO, J. A formação prática dos professores: da prática docente na instituição de formação à prática pedagógica nas escolas. Revista Portuguesa de Formação de Professores, [S.1.], v.1, p.37-54, 2001.

FRANFORT-NACHIMAS, C.; NACHIMAS, D. Research methods in the social sciences. 5th.ed. New York: Longman, 1996. FROBER, K.; MADELLA, A.; TOKARSKI, W. (Eds.). Higher education in sport in Europe: from labour market demand to training supply. Maidenhead: Meyer \& Meyer Sport, 2008. p.80-108.

GOETZ, J.; LE COMPTE, M. Ethnography and qualitative design in educational research. New York: Academic Press, 1984. GONZI, A. Developing a competent workforce. Adelaide: National Centre for vocational Education Research, 1994. GONZI, A.; HAGER, P.; ATHANASOU, J. The development of competency-based assessment strategies for the professions: national office of overseas skills recognition research article. Canberra: Australian Government Publishing Service, 1993.

GOULD, D.; GIANNINI, J.; KRANE, V.; HODGE, K. Educational needs of elite US national team, Pan-American and Olympic Coaches. Journal of Teaching in Physical Education, Champaign, v.9, n.4, p.332-44, 1990.

GRAÇA, A. Conhecimento do professor de Educação Física. In: BENTO, J. (Ed.). Contextos da pedagogia do desporto. Lisboa: Livros Horizonte, 1999. p.168-251.

GRATTON, C.; JONES, I. Research methods for sport studies. London: Routledge, 2004.

GROSSMAN, P. (Ed.). The making of a teacher: teacher and teacher education. New York: Teaching College, 1990.

HAGER, P.; GONCZI, A. What is competence? Medical Teacher, Abingdon, v.18, n.1, p.15-8, 1996.

HONG, J.; STÄHLE, P. The coevolution of knowledge ans competence management. International Journal Management Concepts and Phylosophy, Geneve, v.1, n.2, p.129-45, 2005.

INSTITUTO DO DESPORTO DE PORTUGAL (IDP). Programa nacional de formaçáo de treinadores. Lisboa: IDP, 2010. JONES, R. (Ed.) How can educational concepts inform sports coaching? In: The sports coach as educator: re-conceptualising sports coaching. London: Routledge, 2006. p.3-13.

JONES, R.; WALLACE, M. Another bad day at the training ground: coping with ambiguity in the coaching context. Sport, Education and Society, London, v.10, n.1, p.119-34, 2005.

KIRSHHNER, P.; VILSTEREN, P.; HUMMEL, H.; WIGMAN, M. The design of a study environment and professional competence. Studies in Higher Education, Abingdon, v.22, n.2, p.151-71, 1997.

KOUWENHOVEN, W. Designing for competence in Mozambique: toward a competence-based curriculum for the Faculty of Education of the Eduardo Maondlane. 2003. Doctoral Thesis - University of Twentw, Enschede, 2003. Le BOTERF, G. De la compétence: essai sur un attracteur étranger. Paris: Les Éditions d'Organisation, 1994. 
LESTER, S. Beyond knowledge and competence: toward a framework for professional education. Capability, [S.1.], v.1, n.3, p.1-10, 1995.

LOPES, H. Perfil de competências dos licenciados em engenharia. Lisboa: Instituto Superior Técnico/Gabinete de

Estudos e Planeamento, 2002.

LYSAGHT, R.; ALTSCHULDB, J. Beyond initial certification: the assessment and maintenance of competency in professions. Evaluation and Program Planning, London, v.23, p.95-104, 2000.

MILES, M.; HUBERMAN, M. Qualitative data analysis: an expanded sourcebook. Michigan: Sage, 1994.

PEARSON, A. Competence: a normative analysis. In: COMPETENCE inquires into its meaning and acquisition in educational settings. Lanham: University Press of America, 1984. p.31-40.

PERRENOUD, P. La pédagogie à l'école des différences. Paris: ESF, 1995.

Pedagogia diferenciada: das intençôes à ação. Porto Alegre: Artmed, 1999.

RYCHEN, D.; SALGANIK, L. A holistic model of competence. In: RYCHEN, D.; SAGALNIK, L. (Eds.). Defining and selecting key competencies. Göttingen: Hogrefe \& Huber, 2003. p.45-66.

SANDBERG, J. Human competence at work: an interpretative approach. Göteberg: Göteberg University, 1994. Understanding human competence at work: an interpretative approach. Academy of Management Journal, Columbus, v.43, n.1, p.9-25, 2000.

. Understanding the basis for competence development In: VELDE, C. (Ed.). International perspectives on competence in the workplace. Dordrecht: Kluwer Academic, 2001.

SANTOS, S.; MESQUITA, I.; GRAÇA, A.; ROSADO, A. Coaches' perceptions of competence and acknowledgement of training needs related to professional competences. Journal of Sports Science and Medicine, Bursa, v.9, p.62-70, 2010. SCHEMPP, P.; TEMPLETON, C.; CLARK, B. The knowledge acquisition of expert golf instructors. In: FARRALLY, M.; COCHRAN; A. (Eds.). Science and golf III: proceedings of the world scientific congress of golf. Champaign: Human Kinetics, 1998. p.295-301.

SCHÖN, D. Education the reflexive practitioner. San Francisco: Jossey-Bass, 1987.

The reflective practitioner: how professionals think in action. New York: Basic Books, 1983.

SHULMAN, L. Assessment for teaching: an initiative for the profession. Phi Delta Kappan, Bloomington, v.69, n.1, p.38-44, 1987.

SPENCER, L.; SPENCER, S. (Eds.) Competence at work: Models for superior performance. New York: John Wiley, 1993. STOOF, A.; MARTENS, R.; van MERRIËNBOER, J.; BASTIAENS, T. The boundary approach of competence: a constructivist aid for understanding and using the concept of competence. Human Resource Development Review, St. Paul, v.1, n.3, p.345-65, 2002.

VELVE, C. An alternate conception of competence: implications for vocational education and practice. In: UTS research Centre Vocational Education \& Trainning Working Knowledge: productive learning at work. New South Wales: University of Technology Sydney, 2000.

WALLACE, M.; POCKILINGTON, K. Managing complex educational change: large scale reorganization of schools. London: Routledge, 2002.

WEINERT, F. Concept of competence: a conceptual clarification. In: RYCHEN, D.; SAGALNIK, L. (Eds.). Defining and selecting key competencies. Göttingen: Hogrefe \& Huber, 2001. p.45-66.

WESTERA, W. Competences in education: a confusion of tongues. Journal of Curriculum Studies, Glasgow, v.33, n.1, p.75-88, 2001.

WILLIS, S.; DUBIN, S. Maintaining professional competence. San Francisco: Jossey-Bass, 1990.

ENDEREÇO

Paula Maria Fazendeiro Batista Gabinete de Pedagogia do Desporto

Faculdade de Desporto

Universidade do Porto

R. Dr. Plácido Costa, 91

Recebido para publicação: 22/ 07/ 2010

Revisado: 09/ 12/ 2010

Aceito: 09/02/ 2011

42000-450 - Porto - PORTUGAL

e-mail: paulabatista@fade.up.pt 